\title{
ICE CONDITIONS OF AN ARCTIC POLYNYA: NORTH WATER IN WINTER
}

\author{
By KONRAD STEFFEN \\ (Geographisches Institut, Eidgenössische Technische Hochschule, CH-8057 Zürich, Switzerland)
}

\begin{abstract}
The surface condition of the North Water was investigated during two winters (i.e. the three polynyas: Smith Sound polynya, Lady Ann Strait polynya, and Barrow Strait polynya). Since no detailed information was available on ice conditions and the extent of open water during winter, radiometric temperature measurements of the sea surface had to be taken along a flight line of $2650 \mathrm{~km}$ from an altitude of $300 \mathrm{~m}$. From November to March $1978-79$ and $1980-81,14$ remote-sensing flights were carried out. On the basis of the radiometric measurements, the following ice types were identified: ice-free, dark nilas, light nilas, grey ice, grey-white ice, and white ice. A comparison between the thermal and the visual ice classification (the latter being based on grey tones of the aerial images) showed a deviation of $3 \%$. The analysis showed that in November, December, and January more than $50 \%$ of the Smith Sound polynya was covered by young ice, nilas, and ice-free, whereas in February and March white ice was dominant. Moreover, it was found that the two polynyas in Smith Sound and Lady Ann Strait were much smaller than previously believed. In Barrow Strait, a semi-permanent polynya was observed in the winter of 1980-81. The occurrence of polynyas in Barrow Strait seems to be connected with the location of the fast-ice edge. On the basis of the calculated ice-type distribution and heat-flux rates for different ice types, an energy loss of $178 \mathrm{~W} \mathrm{~m}^{-2}$ was found on the surface of the Smith Sound polynya due to open water and thin ice for the winter months November to March. Compared with other ice-covered sea surfaces in the Arctic, the heat release by the sea-water in the Smith Sound polynya is about $100 \mathrm{~W} \mathrm{~m}^{-2}$ larger.
\end{abstract}

RÉsumé. Conditions des glaces de mer d'une polynie arctique: North Water en hiver. Les conditions en surface du North Water (polynie du Smith Sound, polynie de la Lady Ann Strait et polynie de la Barrow Strait) ont été étudiées lors des deux hivers $1978-79$ et 1980-81. Pour cela les températures radiométriques de la surface de la mer ont été mesurées le long de 14 profils de vol d'une longueur de $2650 \mathrm{~km}$ chacun et à une altitude de $300 \mathrm{~m}$. A l'aide des températures de la surface, les types de glace suivants ont pu être classé; sans glace, nilas sombre, nilas claire, glace grise, glace grise-blanche et glace blanche. La comparaison de la classification thermique avec la classification visuelle, basée sur le ton gris de photos aériennes, a donné une déviation maximale de $3 \%$. Sur la base des mesures le long des profils survolés lors des 2 hivers, les conclusions

\section{INTRODUCTION}

This paper discusses in detail the ice-type distribution in the North Water during winter based on low-level infrared thermometry. For the past two decades, the North Water has drawn scientific attention from the field of glaciology, climatology, oceanography, and biology (Franceschetti and others, 1964; Dunbar, 1969; Nutt, 1969; Muench, 1971; Finley and Renaud, 1980; Dunbar, 1981). The center of the problem is the unusual ice conditions for which the region has been known since William Baffin's voyage in 1616 . The actual North Water covers an area of suivantes peuvent être tirées: les catégories glace jeune, nilas et sans glace recouvrent de novembre à janvier plus de $50 \%$ du North Water, alors qu'en février et mars la glace blanche est dominante. L'étendue de la polynie dans le Smith Sound et la Lady Ann Strait a été beaucoup plus faible qu'initialement prévu. Une polynie semi-permanente a été observée dans la Barrow Strait en hiver 1980-81, dont l'apparition est en relation avec la position avec l'arc de glace ferme. Sur la base de la répartion des différents types de glace et des flux énergétiques de ces différents types, on a déterminé une perte d'énergie de $178 \mathrm{~W} \mathrm{~m}^{-2}$ causée par les zones recouvertes de glace mince lors des mois d'hiver. L'énergie sortant de l'eau de mer de la polynie du Smith Sound est supérieure de $100 \mathrm{~W} \mathrm{~m}^{-2}$ comparé à d'autres régions arctique recouvertes de glace.

ZUSAMMENFASSUNG. Eisverhältnisse einer arktischen Polynya: North Water im Winter. Die Oberflächenverhältnisse im North Water (Smith Sound Polynya, Lady Ann Strait Polynya und Barrow Strait Polynya) wurden während der beiden Winter 1978-79 und 1980-81 untersucht. Dabei wurden radiometrische Temperaturmessungen der Meeresoberfläche entlang von insgesamt 14 Flugprofilen von je $2650 \mathrm{~km}$ Länge aus $300 \mathrm{~m}$ Flughöhe durchgeführt. Mit Hilfe der Oberflächentemperaturmessung konnten die folgenden Eistypen klassifieiert werden: Eisfrei, dunkle Nilas, helle Nilas, graues Eis, grauweisses Eis und weisses Eis. Der Vergleich der thermalen Eisklassifikation mit der visuellen, basierend auf Grautonwerten von Luftbildern, ergab eine maximale Abweichung von 3\%. Anhand der Profilmessungen der beiden Winter kann folgender Schluss gezogen werden: die Kategorien junges Eis, Nilas und Eisfrei bedecken in den Monaten November, Dezember und Januar über $50 \%$ des North Water, während im Februar und März weisses Eis dominiert. Die Ausdehnung der Polynyen im Smith Sound und in der Lady Ann Strait war viel kleiner als ursprünglich angenommen. In der Barrow Strait wurde im Winter 1980-81 eine semipermanente Polynya beobachtet, deren Auftreten mit dem Standort des Festeis-Bogens im Zusammenhang steht. Basierend auf der berechneten Eistypenverteilung und den bekannten Wärmeflussraten verschiedener Eistypen, wurde für die Oberfläche der Smith Sound Polynya ein Energieverlust von $178 \mathrm{~W} \mathrm{~m}^{-2}$ ermittelt, verursacht durch die offenen Wasserstellen und das dünne Eis während der Wintermonate November bis März. Im Vergleich zu anderen eisbedeckten Meeresflächen in der Arktis ist die Wärmeabgabe durch das Meerwasser der Smith Sound Polyna um $100 \mathrm{~W} \mathrm{~m}^{-2}$ grösser.

approximately $80000 \mathrm{~km}^{2}$ (Fig. 1) which is dominated by close pack ice (ice concentration $7 / 10$ to $8 / 10$ ) with many leads and polynyas (located in Lancaster Sound, Barrow Strait, Smith Sound, and Lady Ann Strait) throughout winter. At its northern extremity between Greenland and Ellesmere Island, lat. $79^{\circ} \mathrm{N}$., the North Water is bounded by fast ice, whereas its southern boundary cannot be clearly defined because the concentration of pack ice gradually increases towards Baffin Bay to the south.

Efforts have so far been concentrated on spring, summer, and autumn by means of aircraft and ships' log books (Swithinbank, 1960), aircraft observations (Lindsay, 

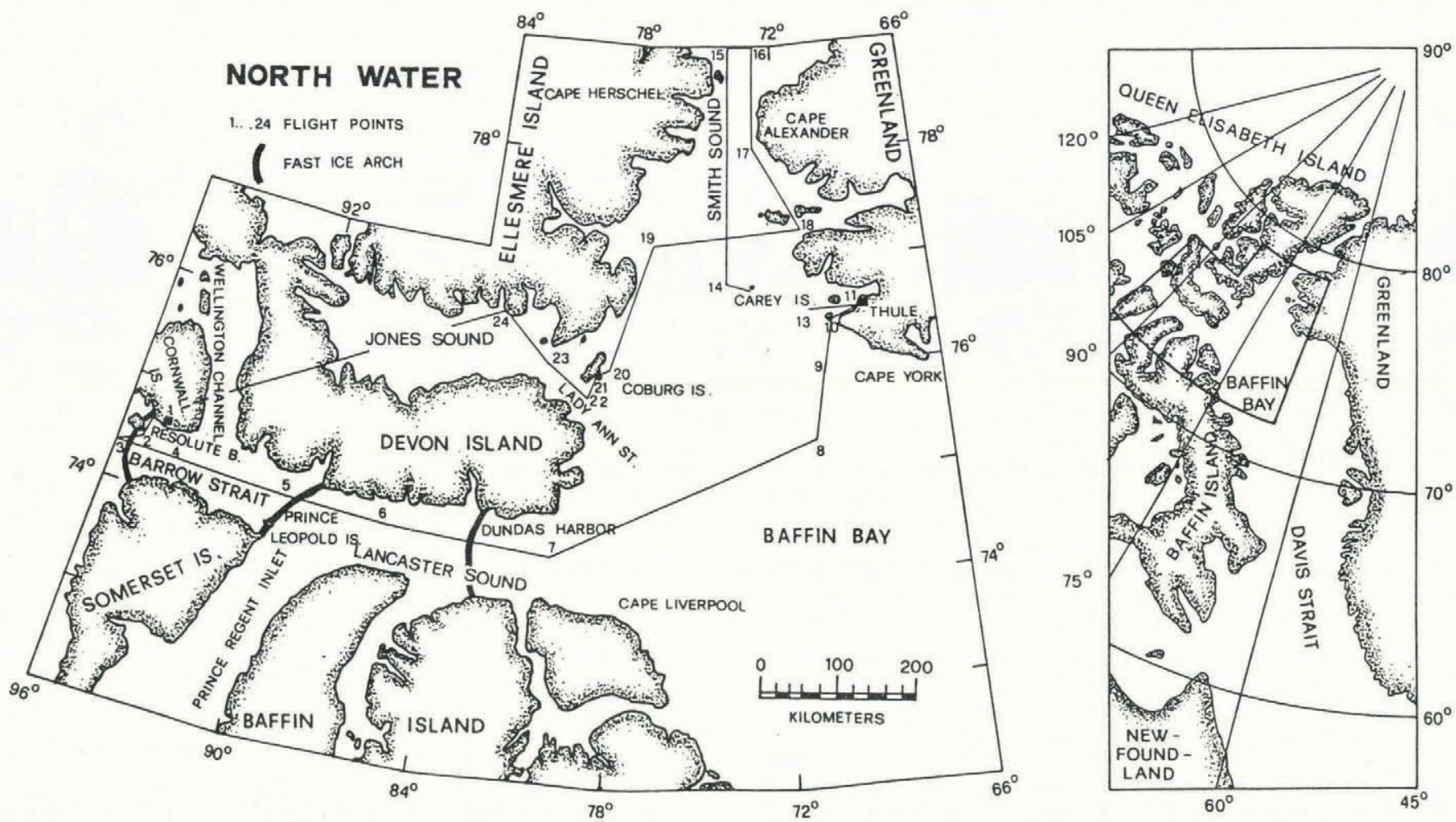

Fig. 1. Map of North Water region and profile of remote sensing. Spring location of fast-ice arch in Barrow Strait-Lancaster Sound for the period between 1961 and 1981.

1976, 1977, 1981), meteorological satellites (Aber and Vowinckel, 1972), NOAA satellites (Smith and Rigby, 1981), and Landsat satellites (Ito, 1982, 1985). It is, however, in winter when the effect of the North Water becomes important; yet, no information on ice conditions is available for that season (Ohmura, unpublished [a]; Steffen and Ohmura, 1985). The satellite-based studies of the dark season carried out on the basis of microwave data (Crawford and Parkinson, 1981) and thermal infra-red data (Dey, 1980, 1981; Smith and Rigby, 1981) are inadequate for the purposes discussed in this paper. (Accuracy and resolution of the satellite imageries are inadequate for many climatological and oceanographical purposes.)

The first low-level reconnaisance flights to be carried out in winter over a limited area of North Water were conducted by Dunbar $(1971,1972)$. Based on radar-scope photography supplemented by visual observations, the amount and distribution of open water was described. The results she obtained showed for the first time that the surface of the North Water, which had been believed to remain open throughout the year (Hayes, 1867), was mainly covered by ice of various types.

In the two winters of $1978-79$ and 1980-81, infra-red thermometry was carried out from a low-flying aircraft as a part of the North Water Project, a glacio-climatological study conducted by McGill University and the Swiss Eidgenössische Technische Hochschule (ETH), Zürich. The primary aim of the investigation was to study the climatological influence the North Water had on its surroundings (Müller and others, 1973). For this purpose, the variability in space and time of the occurrence of different ice types is of great importance.

\section{METHOD OF AIRBORNE MEASUREMENT}

The surface temperature was measured with a Barnes PRT-5 precision radiation thermometer in the thermal infra-red range between 9.5 and $11.5 \mu \mathrm{m}$. A surface area of $100 \mathrm{~m}$ in diameter with a field-of-view of $20^{\circ}$ was obtained. A Twin Otter aircraft was used as an instrument platform to carry out seven horizontal profiles over the area in each winter. The total length of the flight path measured $2650 \mathrm{~km}$ (Fig. 1). The measurements were made at an air speed of $220 \mathrm{~km} / \mathrm{h}$ at a flight altitude of $300 \mathrm{~m}$. The air temperature was recorded at flight level with a Pt-100 resistance thermometer for later atmospheric corrections. In order to classify the sea surface within circular areas of $100 \mathrm{~m}$ in diameter, the ground along the flight path was illuminated by a searchlight Type SX-16 and filmed with a $16 \mathrm{~mm}$ ciné-camera, operated in single release. For the test areas, high-resolution photographs were taken with a Hasselblad camera $(70 \mathrm{~mm}$ film).

The radiation temperature measured with a PRT-5 was corrected by taking into account the emissivity of water $(\epsilon=0.991)$, snow $(\epsilon=0.997)$, and ice surfaces $(\epsilon=0.987)$, the absorption and emission by atmospheric water vapour, as well as the multiple reflection between the cloud base and the ground. The water, snow, and ice surface was assumed to be a grey body in the spectral band 9.5-11.5 $\mu \mathrm{m}$. Furthermore, the temperature-dependence of the emissivity for dry snow was neglected. Young ice surfaces, however, remain wet due to high brine content in the thin ice. Consequently, brightness measurements of sea ice up to $0.25 \mathrm{~m}$ thick were corrected using the emissivity of water. A detailed account of this correction procedure has been presented in Steffen (1985[a]). After having applied the corrections, the relative accuracy of the PRT-5 temperature was estimated at $\pm 0.15^{\circ} \mathrm{C}$ at a flight altitude of $300 \mathrm{~m}$. At a flight altitude of $1500 \mathrm{~m}$, the error increased to $\pm 0.25^{\circ} \mathrm{C}$. Such high accuracy is possible in polar regions where the optical thickness due to water vapour is very small. Even though the concentration of aerosols is reportedly high in Arctic regions (Shaw, 1975), their optical depth is five times smaller than that of water vapour for the spectral band of $9.5-11.5 \mu \mathrm{m}$. The measured surface temperature along the flight profile was used as input data for the seaice classification.

\section{SEA-ICE CLASSIFICATION}

During the two winters of this study (1978-79 and $1980-81)_{3}$ a sea-ice station was established at lat. $74^{\circ} 40^{\prime} \mathrm{N}$., long. $95^{\circ} 10^{\prime} \mathrm{W}$. in Barrow Strait near Resolute Bay, which served as ground truth for the airborne infra-red thermometry as well as a monitor of all energy fluxes on the 
sea ice. The following quantities were recorded during 10 days each month from November to February (1978-79 and 1980-81): temperature profiles in sea ice, in the overlying snow cover, and in the air; incoming and net long-wave radiation; snow depth and density; ice thickness; dew point and wind speed at four different levels. The salinity profile of sea ice was measured every second day. The first measurements were carried out in November with an initial ice thickness of $0.1 \mathrm{~m}$. The evaluation of the flux measurements (sensible heat, latent heat, and conductive heat) and the long-wave radiation balance showed that $70 \%$ of the conductive heat flux was used for the sensible-heat flux at the boundary sea ice-atmosphere in ice up to $0.5 \mathrm{~m}$ thick. The short-wave radiation for this site was negligible during the winter months. From the heat-flux calculations, it was found that different ice types are associated with distinguishable surface-temperature levels.

Both sensible- and latent-heat fluxes are dependent on surface temperature, which in turn is influenced by the ice thickness (Maykut, 1978). They can be parameterized as follows (Budyko, 1974):

$$
0.7 k_{\mathrm{i}}\left[\frac{T_{\mathrm{b}}-T_{\mathrm{S}}}{H}\right]=\rho c_{\mathrm{p}} C_{\mathrm{s}} u\left(T_{\mathrm{s}}-T_{\mathrm{a}}\right)
$$

where $\rho$ is density of the air, $k_{i}$ is heat conductivity of ice, $T_{\mathrm{b}}$ is temperature of the ice bottom, $T_{\mathrm{s}}$ is temperature of the ice surface, $T_{\mathrm{a}}$ is air temperature, $c_{\mathrm{p}}$ is specific heat at constant pressure $\left(1.066 \mathrm{~J} \mathrm{~g}^{-1} \mathrm{~K}^{-1}\right), C_{\mathrm{S}}$ is sensible-heat coefficient at a height of $2 \mathrm{~m}\left(3 \times 10^{-5}\right), u$ is wind speed, and $H$ is the ice thickness.

The conductivity of sea ice depends on its salinity. The following relation proposed by Untersteiner (1961) was used:

$$
k_{\mathrm{i}}=k_{0}+\frac{B S}{T_{\mathrm{S}}-273.15}
$$

where $k_{0}$ is conductivity of pure ice $\left(2.04 \mathrm{~J} \mathrm{~m}^{-1} \mathrm{~K}^{-1} \mathrm{~s}^{-1}\right), S$ is salinity, and $B$ is a constant $\left(117.3 \mathrm{~J} \mathrm{~m}^{-1} \mathrm{~s}^{-1}\right)$.

After combining Equations (1) and (2), the ice thickness can be expressed as a function of surface temperature, air temperature, and wind speed:

$$
H=\frac{0.7\left(T_{\mathrm{b}}-T_{\mathrm{s}}\right)\left[\frac{B S}{T_{\mathrm{s}}-273.15}+k_{0}\right]}{\rho c_{\mathrm{p}} C_{\mathrm{s}} u\left(T_{\mathrm{s}}-T_{\mathrm{a}}\right)} .
$$

Figure 2 depicts the calculated ice thickness by Equation (3) as a function of surface temperature and air temperature, for a wind speed of $2 \mathrm{~m} \mathrm{~s}^{-1}$. For ice-bottom temperature $\left(T_{\mathrm{b}}\right)$, a constant value of $-1.8^{\circ} \mathrm{C}$ was assumed. For the purpose of comparison, the measurements obtained from the sea-ice station (Resolute Bay) are presented in

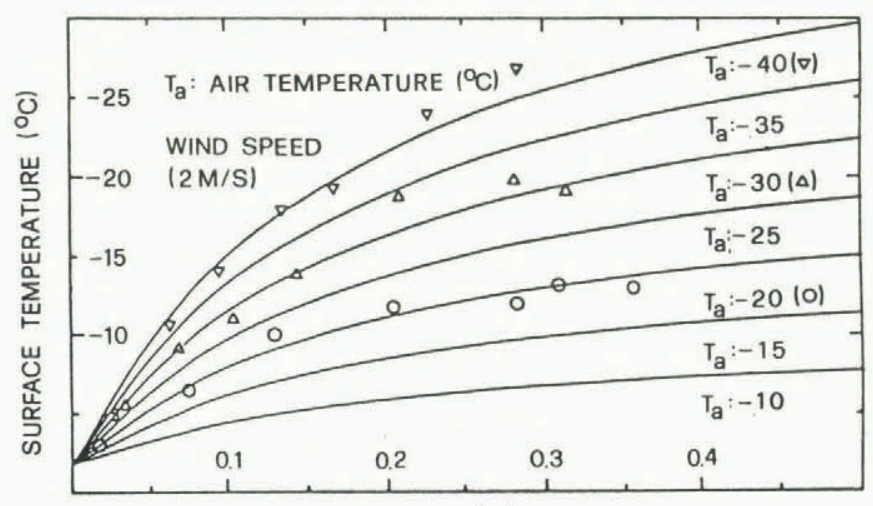

ICE THICKNESS (M)

Fig. 2. Ice thickness $H$ as a function of the surface temperature $T_{\mathrm{S}}$ and the air temperature $T_{\mathrm{a}}$ at a wind speed of $2 \mathrm{~m} \mathrm{~s}^{-1}$ (calculated values determined by Equation (3)). Dots: measurement results from the Resolute Bay sea-ice station.
Figure 2 for various surface and air temperatures. Wind speed during the measurement ranged between 2 and $5 \mathrm{~m} \mathrm{~s}^{-1}$.

The snow cover on sea ice has an insulating effect on conduction. On the other hand, recent measurements by Crocker (1984) have shown that the snow cover overlying young sea ice contains large quantities of salt. This increases the thermal conductivity of the snow by up to $50 \%$. The thermal conductivity of snow on young ice is, however, still five times smaller than that of ice. This causes a significantly reduced surface temperature which has to be taken into account for thermal classification of sea ice in general. For the North Water region, the snow cover on young ice, nilas, and new ice will not exceed $20 \mathrm{~mm}$ in thickness (Steffen, 1985[a]). The resulting surfacetemperature reduction is in the order of 1 deg for dark nilas (assumed snow depth: $5 \mathrm{~mm}$ ), 2 deg for grey ice (snow depth: $15 \mathrm{~mm}$ ), and $4 \mathrm{deg}$ for grey-white ice (snow depth $20 \mathrm{~mm}$ ), and is negligible, since it lies within the temperature-classsification band of ice types. For ice types thicker than $0.3 \mathrm{~m}$ (white ice), the insulation effect of the snow cover must, however, be taken into account.

In the following, the effects of uncertainties in wind speed $(u)$, air temperature $\left(T_{\mathrm{a}}\right)$, and the 0.7 -coefficient $(K)$ on the calculated ice thickness ( $H$; Equation (3)) will be discussed. The resulting ice-thickness difference for a change in coefficient $K$ of 0.05 is $3 \mathrm{~mm}$ for dark nilas; a change of 0.1 results in an ice-thickness difference of $42 \mathrm{~mm}$ for grey-white ice. An uncertainty in the coefficient $K$ of \pm 0.1 at the most is expected for ice less than $0.5 \mathrm{~m}$ in thickness; therefore, the error in the calculated ice thickness is minor. Ice-thickness calculations are more sensitive to uncertainties in air temperature and wind speed which show the following comparison: an uncertainty in air temperature of 5 deg $\left(T_{\mathrm{a}}=-25^{\circ} \mathrm{C}\right)$ for dark nilas $\left(T_{\mathrm{S}}=-5^{\circ} \mathrm{C}\right)$ results in an ice-thickness difference of $2 \mathrm{~mm}$. For grey-white ice $(H=0.4 \mathrm{~m})$, such an uncertainty in air temperature results in an ice-thickness difference of $0.2 \mathrm{~m}$. For thin ice like nilas, this error can be neglected; for thicker ice like grey-white ice, the ice-thickness error can be as large as $100 \%$. However, the air temperature along the flight profile is known to an accuracy better than $5 \mathrm{deg}$, as frequent airtemperature measurements at different flight levels $(300 \mathrm{~m}$, $100 \mathrm{~m}$, and $50 \mathrm{~m}$ ) over the same area along the flight profile were carried out. The difference in ice thickness for an uncertainty in wind speed of $1 \mathrm{~m} \mathrm{~s}^{-1}$ for wind speeds less than $3 \mathrm{~m} \mathrm{~s}^{-1}$ is $30 \%$ at the most, and for wind speeds greater than $3 \mathrm{~m} \mathrm{~s}^{-1}$ the error is of the order of $10 \%$. In the North Water area the measured surface wind exceeded $5 \mathrm{~m} \mathrm{~s}^{-1}$ throughout the winter (Steffen, 1985[b]).

To verify the thermal ice-type classification, a test area of $200 \mathrm{~km}^{2}$ located in Smith Sound was chosen for visual comparison. The surface temperature was recorded along ten profiles each of $40 \mathrm{~km}$ at an altitude of $1500 \mathrm{~m}$. The profile distance of $500 \mathrm{~m}$ resulted in a $6 \%$ overlap between adjoining measurement bands. In addition to the temperature measurements, a Hasselblad 500EL camera was used to photograph the surface conditions in detail. The Zeiss Planar $80 \mathrm{~mm}$ lens provided a $25 \%$ overlap. The high-resolution pictures served as a basis for a photo-mosaic map from which the ice types were classified visually according to their grey tone. The percentages of different ice types were measured on a digitizer table. It is believed that the accuracy for the visual ice classification is better than $1 \%$. This visual sea-ice type classification provided the basis for a comparison with the thermal ice classification calculated from Equation (3).

The thermal classification was established as follows: the ice thickness was calculated from the surfacetemperature measurements after Equation (3) and classified according to Table $I$. The wind speed was calculated on the basis of the navigation data and the flying time needed to cover the distance. The calculated wind speed was extrapolated from the flight altitude to $10 \mathrm{~m}$ above ground with the assumption of a logarithmic wind profile; it varied within the range of $5-12 \mathrm{~m} \mathrm{~s}^{-1}$. With this classification method, first-year ice and old ice cannot be further distinguished for two reasons: (1) the ratio of sensible heat $\left(Q_{\mathrm{s}}\right)$ to conductive heat $\left(Q_{\mathrm{c}}\right)$ for ice thicker than $0.5 \mathrm{~m}$ is 
TABLE I. SEA-ICE CLASSIFICATION (WORLD METEOROLOGICAL ORGANIZATION, 1970). VISUAL VERSUS THERMAL ICE-TYPE CLASSIFICATION IN THE TEST AREA OF $200 \mathrm{~km}^{2}$

Ice type

Visual

Thermal Ice

classification classification thickness

$\mathrm{m}$

$\begin{array}{lrrc}\text { Ice-free } & 3 \% & >1 \% & 0 \\ \text { Dark nilas and new ice } & 19 \% & 16 \% & <0.05 \\ \text { Light nilas } & 10 \% & 9 \% & 0.05-0.10 \\ \text { Grey ice } & 12 \% & 14 \% & 0.10-0.15 \\ \text { Grey-white ice } & 37 \% & 39 \% & 0.15-0.30 \\ \text { White ice } & 19 \% & 21 \% & >0.30\end{array}$

less than 0.7 , and consequently ice-thickness calculations after Equation (3) are inaccurate; (2) the insulation effect of the snow cover cannot be neglected for ice thicker than $0.5 \mathrm{~m}$, but accurate snow-depth data are missing. Therefore, first-year ice and old ice will be called white ice. For the present purposes, however, this is not a crucial problem since medium first-year ice, thick first-year ice, second-year ice, and multi-year ice are not likely to be found in the North Water area. Furthermore, ice types such as new ice and dark nilas, which are both $0.05 \mathrm{~m}$ thick, cannot be distinguished by the present method. According to this classification, new ice will be called dark nilas.

The comparison between the thermal ice classification and the visual observations based on the grey tones of air photographs gave the following results (Table I).

Ice-free areas, new ice, and nilas were under-rated in the comparison between the thermal and the visual ice classification for the following reasons:

(1) At an altitude of $1500 \mathrm{~m}$, the spatial resolution resulting from the PRT-5 instrument corresponds to a circular area of $0.2 \mathrm{~km}^{2}$. Ice types covering only small areas (new ice and nilas) of less than $0.2 \mathrm{~km}^{2}$ will be classified according to the temperature averaged over the entire circular area.

(2) A strong northerly wind prevailed in the area while the measurements were being taken, fracturing the sea ice into ice floes and small fragments of ice. The resulting small ice-free areas were also too small to be within the range of the thermal measurement resolution.

\section{RESULTS AND DISCUSSION}

The ice types were classified along the flight path according to the method described above. The same profile coordinates were used for all 14 flights. The ice-type percentages of equal profile distances are therefore comparable, although the ice distribution of large areas cannot generally be derived from a single profile measurement. For the study of polynyas, however, the profile method carried out along the same flight path on each flight renders valuable information on the spatial distribution and temporal variation of open water and different ice types. For the study of polynyas, open water and thin ice are of particular interest because of the large energy loss from the sea surface. The findings of this study will be presented in detail separately for the Lady Ann Strait polynya, Barrow Strait polynya, and Smith Sound polynya for the winters of $1978-79$ and $1980-81$.

\section{Lady Ann Strait}

Lady Ann Strait polynya is situated between Jones Sound and Baffin Bay, south of Coburg Island. Its western end is a U-shaped fast-ice edge that can vary in location from year to year by about $50 \mathrm{~km}$, as can be seen from the sea-ice atlas of Lindsay (1981).

The ice types of a polynya consist, by definition (World Meteorological Organization, 1970), of new ice, nilas, and young ice, which are less than $0.3 \mathrm{~m}$ thick (Table I). However, this definition did not always apply to the ice types found in Lady Ann Strait (Table II) during the winter of 1978-79. For five out of seven flying dates between November and March, only approximately $70 \%$ of the ice types were classified as nilas, young ice, and ice-free. On 5 February 1979, even white ice was dominant. In the second winter of the study, on 2 December 1980, white ice comprised $100 \%$ of the profile. On 12 December 1980, white ice was still dominant. Between 12 and 29 December of the same year, a drastic change occurred when more than $95 \%$ of the ice types were nilas and ice-free. On the remaining four flights, on 22 January, 7 February, 3 and 7 March 1981 , young ice and nilas were dominant.

It is interesting to note that, according to the thermal measurements, only a few per cent of the total profile length were ice-free in both winters. The visual observations, on the other hand, showed numerous ice-free areas. These had, however, a dimension below the ground resolution of the PRT-5 instrument of $0.2 \mathrm{~km}^{2}$ and were therefore classified according to the mean temperature of open water. No decrease in the percentage of young ice was observed with time in either winter. In the winter of 198081 , even the opposite occurred, when most of the polynya surface was already covered with white ice in early winter. This is not surprising, since strong westerly winds and the resulting upswelling of water are the main cause for this polynya (Steffen, 1985[b]).

\section{Smith Sound}

For the Smith Sound area, the thermal ice classification was carried out along a profile of $824 \mathrm{~km}$ (point 9 to 19 , Fig. 1). This profile covers the area that is well known as the Smith Sound polynya, which includes Smith Sound as well as the area north of the Carey Islands.

In November and December 1978, between $50 \%$ and $75 \%$ of the profile (Table III) was covered by dark nilas, light nilas, grey ice and grey-white ice, and ice-free. On 10 January and 24 February 1979, less than $10 \%$ of the ice was classified as white ice. On these two flights, strong northerly winds with speeds exceeding $40 \mathrm{~m} \mathrm{~s}^{-1}$ were observed. The Smith Sound profile was not measured in its full length (turn $50 \mathrm{~km}$ south of point 15) because of strong air turbulence. On the remaining two flights on 22 February and 3 March, the percentages of white ice were $75 \%$ and $60 \%$, respectively. On 2,20 , and 29 December 1980 , and 22 January 1981, young ice, nilas, and ice-free occupied between $50 \%$ and $75 \%$ of the area along the profile. The percentage of these ice types decreased on 7 February to $45 \%$, and on 2 and 16 March even to $20 \%$.

On the basis of the 2 years of measurements, the following conclusions can be drawn: in November, December, and January, young ice, nilas, and ice-free covered more than $50 \%$ of the Smith Sound polynya. A vast ice-free area with a profile length of up to $140 \mathrm{~km}$ occurred only during the period mentioned above. Therefore, Nutt's (1969) assumption that vast areas were ice-free during the winter months cannnot be confirmed on the basis of these profile measurements.

In the eastern part of Smith Sound, in the vicinity of Cape Alexander, the largest ice-free areas were observed during the two winters. Because of frequent storms, Cape Alexander is reportedly the only place in this part of Greenland where the ice cover never freezes into a strong and persisting field (Arctic Canada, 1978). It was this region where surface-water temperatures between $-1.7^{\circ}$ and $-0.1^{\circ} \mathrm{C}$ were measured in winter, which is believed to have resulted from wind-induced upwelling (Steffen, 1985[b]). Since this area is of special interest because of its thin ice cover, the data set for the winter of 1980-81 will be given (Table IV). The flight profile chosen for the ice-type classification has a length of $50 \mathrm{~km}$ and lies north of point 17 (Fig. 1). On 2 and 20 December 1980, the percentage of white ice amounted to less than $2 \%$. The ice-free areas covered $62 \%$ and $35 \%$, respectively, of the profile length. Prior to the third flight, on 29 December 1980, a large low-pressure cell with its center in Barrow Strait covered the entire Canadian Arctic Archipelago. According to the synoptic weather map, only weak surface winds could be expected in Smith Sound (Steffen, 1985[a]), which explains why the whole area was covered by ice. On 22 January 


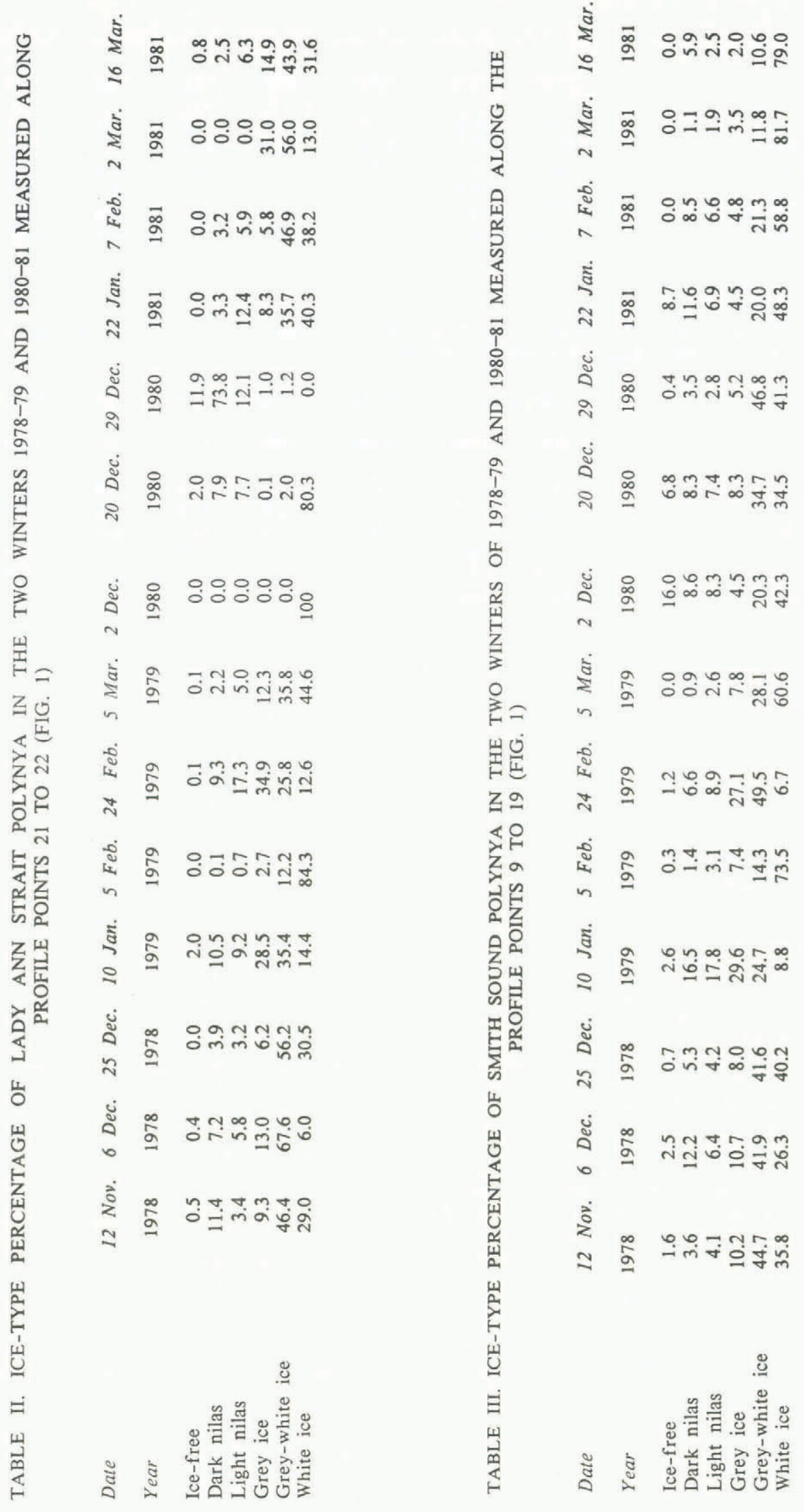


TABLE IV. ICE-TYPE PERCENTAGE IN THE VICINITY OF CAPE ALEXANDER (PART OF SMITH SOUND POLYNYA) IN THE WINTER 1980-81 FOR A PROFILE LENGTH OF $50 \mathrm{~km}$ LOCATED NORTH OF POINT 17 (FIG. 1)

\begin{tabular}{|c|c|c|c|c|c|c|c|}
\hline Date & 2 Dec. & $20 \mathrm{Dec}$. & $29 \mathrm{Dec}$. & 22 Jan. & $2 \mathrm{Feb}$. & 2 Mar. & $16 \mathrm{Ma}$ \\
\hline Year & 1980 & 1980 & 1980 & 1981 & 1981 & 1981 & 1981 \\
\hline Ice-free & 62.2 & 35.2 & 0.8 & 52.9 & 0.0 & 0.0 & 0.0 \\
\hline Dark nilas & 16.1 & 29.3 & 9.9 & 35.9 & 29.3 & 0.0 & 27.1 \\
\hline Light nilas & 4.5 & 9.2 & 5.1 & 8.7 & 18.7 & 4.5 & 7.2 \\
\hline Grey ice & 2.7 & 14.6 & 13.1 & 1.0 & 12.7 & 14.7 & 3.7 \\
\hline Grey-white ice & 13.3 & 9.8 & 48.6 & 1.5 & 22.1 & 34.2 & 8.2 \\
\hline White ice & 1.3 & 1.9 & 22.5 & 0.0 & 17.9 & 46.6 & 53.8 \\
\hline
\end{tabular}

TABLE V. ICE-TYPE PERCENTAGE OF BARROW STRAIT IN THE WINTER OF 1980-81 MEASURED ALONG PROFILE POINTS 1 TO 4 (FIG. 1)

\begin{tabular}{|c|c|c|c|c|c|c|c|}
\hline Date & 2 Dec. & 20 Dec. & $29 \mathrm{Dec}$. & 22 Jan. & $2 \mathrm{Feb}$. & 2 Mar. & $16 \mathrm{Ma}$ \\
\hline Year & 1980 & 1980 & 1980 & 1981 & 1981 & 1981 & 1981 \\
\hline Ice-free & 1.0 & 1.2 & 0.0 & 3.8 & 0.8 & 0.0 & 0.0 \\
\hline Dark nilas & 0.2 & 2.7 & 0.0 & 2.6 & 11.0 & 0.0 & 0.0 \\
\hline Light nilas & 0.4 & 0.6 & 0.0 & 1.0 & 14.9 & 0.0 & 0.0 \\
\hline Grey ice & 0.2 & 0.5 & 0.1 & 1.5 & 14.8 & 0.0 & 0.0 \\
\hline Grey-white ice & 3.4 & 6.0 & 0.2 & 1.9 & 13.7 & 0.2 & 0.3 \\
\hline White ice & 94.8 & 89.0 & 99.7 & 89.2 & 44.8 & 99.8 & 99.7 \\
\hline
\end{tabular}

1981 , vast areas were again ice-free $(>53 \%)$ and all ice types were classified as nilas and young ice. In February and March, the percentage of white ice rose again and reached its peak at $54 \%$ on 16 March 1981, the end of the observation period.

\section{Barrow Strait}

In the winter of $1978-79$, the sea ice in Barrow Strait was land-fast during December and January. In the winter of 1980-81, however, a semi-permanent polynya was observed south of Cornwallis Island. The ice-type distribution can be described as follows: in December, the pack ice consisted mainly of white ice (Table V). Numerous leads contributed merely a few per cent of young ice and nilas along the flight profile. On 22 January, and especially on 7 February 1981, vast areas were covered by young ice and nilas. Surface-water temperatures above the freezing point of sea-water $\left(-1.7^{\circ}\right.$ to $\left.-0.1^{\circ} \mathrm{C}\right)$ were also measured in the ice-free areas during that period (Steffen, 1985[b]). In March, the ice cover in Barrow Strait became land-fast. The new fast-ice edge moved $200 \mathrm{~km}$ eastward and was found again at the entrance of Prince Regent Inlet to Lancaster Sound (Fig. 1).

It is interesting to note that, in some years, the fastice edge in Barrow Strait and Lancaster Sound changes its location by $400 \mathrm{~km}$ from one extreme to the other. This has also been shown in the three sea-ice atlases by Lindsay $(1976,1977,1981)$ and the one by Ito (1982). The year-toyear variations are summarized in Table VI.

The atlases by Lindsay are based on aerial reconnaisance flights which were carried out not before March-April $(1967-78)$ or June $(1961-66)$. The atlas by Ito is based on Landsat satellite imagery that depended on daylight and therefore does not contain any satellite imagery taken before mid-March. The data of the two atlases could lead to the conclusion that the fast-ice edge is predominantly found in the area of Maxwell Bay-Prince Leopold Island. The winter remote-sensing measurements discussed in this paper show, however, that from December to February the fast-ice edge is not necessarily in the same position as in spring.

\section{ENERGY BUDGET OVER NORTH WATER}

The supply of keat from the sea-water and the latent heat of ice formation is compensated by the loss of energy due to sensible heat, latent heat, and long-wave radiation. This energy loss due to the open water and the thin ice cover was calculated for the Smith Sound polynya (flight points 9 to 19; Fig. 1) on the basis of the heat-flux rates for different ice types (Maykut, 1978), and the ice-type percentages measured along the flight profile. From November to March, the calculated heat loss on the air-sea interface has a mean value of $178 \mathrm{~W} \mathrm{~m}^{-2}$ for the area of the Smith Sound polynya (Table VII). The heat balance for the entire North Water region was first calculated by Ohmura (unpublished [a]). For comparable periods, the results correspond very well with the present investigation.

The latent heat of sea-ice formation $\left(L_{s}\right)$ depends on the relative proportions of pure ice and brine in the newly formed ice. Schwerdtfeger (1963) has parameterized this relation as following:

$$
L_{\mathrm{S}}=\left(1-S_{\mathrm{i}}-S_{\mathrm{i}} / S_{\mathrm{w}}\right) L_{\mathrm{i}}
$$

where $S_{\mathrm{i}}$ is salinity of sea ice, $S_{\mathrm{w}}$ is salinity of sea-water,

TABLE VI. SPRING LOCATION OF THE FAST-ICE EDGE IN BARROW STRAIT AND LANCASTER SOUND FOR THE YEARS OF 1961 TO 1981 (FOR LOCATION SEE FIGURE 1)

Location of fast-ice edge

Cornwallis Island-Sommerset Island

Maxwell Bay-Prince Leopold Island

Dundas Harbor-Borden Peninsula
Years 
TABLE VII. ENERGY LOSS ON THE SURFACE OF THE SMITH SOUND POLYNYA DUE TO OPEN WATER AND THIN ICE. CALCULATION BASED ON HEAT-FLUX RATES FOR DIFFERENT ICE TYPES (MAYKUT, 1978) AND THE MEASURED ICE-TYPE DISTRIBUTION ALONG THE FLIGHT LINE (FLIGHT POINT 9 TO 19; FIG. 1)

\begin{tabular}{rcrc}
\multicolumn{1}{c}{ Date } & $\begin{array}{c}\text { Energy loss } \\
\mathrm{W} \mathrm{m}^{-2}\end{array}$ & \multicolumn{1}{c}{ Date } & $\begin{array}{c}\text { Energy loss } \\
\mathrm{W} \mathrm{m}^{-2}\end{array}$ \\
11 Nov. 1978 & 147 & 2 Dec. 1980 & 267 \\
12 Dec. 1978 & 204 & 20 Dec. 1980 & 214 \\
25 Dec. 1978 & 153 & 28 Dec. 1980 & 141 \\
10 Jan. 1979 & 272 & 22 Jan. 1981 & 226 \\
2 Feb. 1979 & 113 & 2 Feb. 1981 \\
24 Feb. 1979 & 245 & 2 Mar. 1981 & 151 \\
3 Mar. 1979 & 132 & 16 Mar. 1981 & 107 \\
Mean & 181 & Mean & 110
\end{tabular}

and $L_{\mathrm{i}}$ is latent heat of pure ice. For the lowest $50 \mathrm{~mm}$ of the sea ice, the mean salinity value for nilas and young ice was found to be $16^{\circ} / 00$ (Steffen, 1985[a]). Ice formation of $20 \mathrm{~mm} \mathrm{~d}^{-1}$ was found from ice-thickness measurements in this area. Therefore, if we consider Equation (4) $\left(S_{\mathrm{i}}=0.016 \%\right.$ ans $\left.S_{\mathrm{w}}=0.033 \%\right)$, the supply of heat by refreezing is $38 \mathrm{~W} \mathrm{~m}^{-2}$ at the most. If we substract this value from the calculated heat loss of $178 \mathrm{~W} \mathrm{~m}^{-2}$, we find that the remaining $140 \mathrm{~W} \mathrm{~m}^{-2}$ or more must be withdrawn from the enthalpy in the sea-water. For the Central Polar Ocean, Vowinckel and Orvig (1966) found an oceanic heat flux of $38 \mathrm{~W} \mathrm{~m}^{-2}$ for the same time period (November-March). For Baffin Bay, an oceanic heat flux of $23 \mathrm{~W} \mathrm{~m}^{-2}$ was found for the above-mentioned period on the basis of ocean currents and heat-storage change estimates (Walmsley, 1966). Therefore, the difference in heat release by the sea-water between the Smith Sound area and other ice-covered sea surfaces in the Arctic is in the order of $100 \mathrm{~W} \mathrm{~m}^{-2}$ or more.

\section{CONCLUSIONS}

The main purpose of the thermal ice-type classification was to study temporal and spatial variations of sea ice in a polynya. Ice types thicker than $0.3 \mathrm{~m}$ are absent from a polynya by definition (World Meteorological Organization, 1970). From the low-level infra-red thermometry measurements of the two winters of $1978-79$ and 1980-81, the following conclusion can be drawn for all three polynyas in the North Water area: in Lady Ann Strait, only one out of 14 flight measurements showed the ice types characteristic of a polynya, i.e. ice-free, dark nilas, light nilas, grey ice, and grey-white ice. On other flights, white ice was found to cover $50 \%$ of the profile length. In the Smith Sound area, none of the 14 flight measurements gave proof of a polynya by definition. However, in November, December, and January, young ice, nilas, and ice-free covered more than $50 \%$ of the Smith Sound polynya. In February and March, white ice was dominant with the one exception of 24 February 1979. In Barrow Strait, a semi-permanent polynya was observed. This seems to be connected with the location of the fast-ice edge which moved eastward by approximately $200 \mathrm{~km}$ in the second half of the winter. The visual observations in spring (satellite and aircraft) did not always provide accurate information on whether a polynya had occurred in Barrow Strait during winter.

The quantitative analysis of the different ice types in Lady Ann Strait and the Smith Sound area shows that the polynyas were much smaller than previously believed (Stirling and Cleator, 1981). Polynyas are limited to small areas along the fast-ice edge (Lady Ann Strait) or along the coast (vicinity of Cape Alexander, Smith Sound). In the latter area, exclusively young ice, nilas, and ice-free was found during three out of the four flights in December 1980 and January 1981.

The ice-thickness distribution in a polynya plays an important role in determining the large-scale heat input to the atmosphere boundary layer. Despite the extremely rapid decrease in energy-exchange rates as ice forms in open water, young ice with a thickness of $0.3 \mathrm{~m}$ still has a net heat loss of an order of magnitude larger than that of multi-year ice. The energy loss for the Smith Sound polynya due to open water and thin ice cover was found to be $178 \mathrm{~W} \mathrm{~m}^{-2}$ for the months November-March. Considering an energy supply by refreezing of $38 \mathrm{~W} \mathrm{~m}^{-2}$, the remaining $140 \mathrm{~W} \mathrm{~m}^{-2}$ must be withdrawn from the enthalpy in the seawater. The heat release by the sea-water in the Smith Sound area is one of the largest in the High Arctic and in the order of $100 \mathrm{~W} \mathrm{~m}^{-2}$ larger compared with other ice-covered sea surfaces.

\section{ACKNOWLEDGEMENTS}

Flight time and the logistic support in the field were generously provided by the Polar Continental Shelf Project of the Department of Energy, Mines and Resources of Canada. Financial support for the project came from the Government of Canada (contract No. OSU76-00151), the U.S. National Science Foundation (contract No. DPP-7826132), Swiss National Science Foundation (contract No. 2.8807-0.77), and Petro Canada Ltd, Calgary, Canada.

The author wishes to acknowledge support from numerous agencies and individuals, and especially the excellent field assistance of D. Fisher, G. Crocker, and R. Leuenberger, as well as $\mathrm{Dr}$ A. Ohmura's helpful suggestions with the analysis and useful comments after reading the draft manuscript. The author profited by the constructive comments of the reviewer.

\section{REFERENCES}

Aber, P.G., and Vowinckel, E. 1972. Evaluation of North Water spring ice cover from satellite photographs. Arctic, Vol. 25, No. 4, p. 263-71.

Budyko, M.I. 1974. Climate of life. New York and London, Academic Press. (International Geophysical Series 18.)

Canada. Department of Fisheries and the Environment. 1978. Arctic Canada. Sailing directions. Vol. 2. Ottawa, Department of Fisheries and the Environment.

Crawford, J., and Parkinson, C.L. 1981. Wintertime microwave observation of the North Water polynya. (In Gower, J.F.R., ed. Oceanography from space. London, Plenum Press, p. 839-44. (Marine Science, Vol. 13.))

Crocker, G.B. 1984. A physical model for predicting the thermal conductivity of brine-wetted snow. Cold Regions Science and Technology, Vol. 10, No. 1, p. 69-74.

Dey, B. 1980. Applications of satellite thermal infrared images for monitoring North Water during the periods of polar darkness. Journal of Glaciology, Vol. 25, No. 93, p. 425-38.

Dey, B. 1981. Monitoring winter sea ice dynamics in the Canadian Arctic with NOAA-TIR images. Journal of Geophysical Research, Vol. 86, No. C4, p. 3223-35. 
Dunbar, M. 1969. The geographical position of the North Water. Arctic, Vol. 22, No. 4, p. 439-41.

Dunbar, M. 1971. Winter ice reconnaissance in Nares Strait 1970-71. Ottawa, Defence Research Board of Canada. (DREO Technical Note No. 71-34.)

Dunbar, M. 1972. Winter ice reconnaissance in Nares Strait, 1971-72. Ottawa, Defence Research Board of Canada. (DREO Technical Note No. 72-30.)

Dunbar, M.J. 1981. Physical causes and biological significance of polynyas and other open water in sea ice. (In Stirling, I., and Cleator, H., eds. Polynyas in the Canadian Arctic. Ottawa, Canadian Wildlife Service, p. 29-40. (Occasional Paper No. 45.))

Finley, K.J., and Renaud, W.E. 1980. Marine mammals inhabiting the Baffin Bay North Water in winter. Arctic, Vol. 33, No. 4, p. 724-38.

Franceschetti, A.P., and others. 1964. Oceanographic observations, Kennedy Channel, Kane Basin, Smith Sound and Baffin Bay, summer 1963, by A.P. Franceschetti, D.A. $M c$ Gill, N. Corwin, and E. Uchupi. Washington, DC, United States Coast Guard. (Oceanographic Report No. 5.)

Hayes, I.I. 1867. Physical observations in the Arctic seas. Smithsonian Contributions to Knowledge, Vol. 15, No. 196, p. 223-41.

Ito, H. 1982. Sea ice atlas of northern Baffin Bay. Zürcher Geographische Schriften, No. 7.

Ito, H. 1985. Decay of the sea ice in the North Water area: observation of ice cover in Landsat imagery. Journal of Geophysical Research, Vol. 90, No. D5, p. 8102-10.

Lindsay, D.G. 1976. Sea-ice atlas of Arctic Canada 1961-1968. Ottawa, Department of Energy, Mines and Resources.

Lindsay, D.G. 1977. Sea-ice atlas of Arctic Canada 1969-1974. Ottawa, Department of Energy, Mines and Resources.

Lindsay, D.G. 1981. Sea-ice atlas of Arctic Canada 1975-1978. Ottawa, Department of Energy, Mines and Resources.

Maykut, G.A. 1978. Energy exchange over young sea ice in the central Arctic. Journal of Geophysical Research, Vol. 83, No. C7, p. 3646-58.

Muench, R.D. 1971. The physical oceanography of the northern Baffin Bay region. Washington, DC, Arctic Institute of North America. Baffin Bay-North Water Project. (Scientific Report No. 1.)

Müller, F., and others. 1973. Das North Water-Projekt (kanadisch-grönländische Hocharktis), by F. Müller, A. Ohmura, and R. Braithwaite. Geographica Helvetica, Bd. 28, No. 2, p. 111-17.
Nutt, D.C. 1969. The North Water of Baffin Bay. Polar Notes. Occasional publication of the Stefansson Collection, No. 9, p. 1-25.

Ohmura, A. Unpublished [a]. The climate of North Water 1972-75. (In Müller, F., and others, eds. North Water Project. Progress report 1 October 1974 to 30 September 1975. Edited by F. Müller and 7 others. Zürich, ETH; Montreal, McGill University, p. 14-54.)

Ohmura, A. Unpublished [b]. The reevaluation of the radiation budget and energy balance for the surface of North Water. (In Müller, F., and others, eds. North Water Project. Progress report VI. 1 April 1978 to 31 December 1979. Edited by F. Müller. P. Berger, H. Ito, A. Ohmura, $K$. Schroff, and $K$. Steffen. Zürich, ETH; Montreal, McGill University, p. 2-6.)

Schwerdtfeger, P. 1963. The thermal properties of sea ice. Journal of Glaciology, Vol. 4, No. 36, p. 789-807.

Shaw, G.E. 1975. The vertical distribution of tropospheric aerosols at Barrow, Alaska. Tellus, Vol. 27, No. 1, p. 39-50.

Smith, M., and Rigby, B. 1981. Distribution of polynyas in the Canadian Arctic. (In Stirling, I., and Cleator, H., eds. Polynyas in the Canadian Arctic. Ottawa, Canadian Wildlife Service, p. 7-28. (Occasional Paper No. 45.))

Steffen, K. 1985[a]. Surface temperatures and ice types of an Arctic polynya: North Water in winter. Zürcher Geographische Schriften, No. 19.

Steffen, K. 1985[b]. Warm water cells in the North Water, northern Baffin Bay during winter. Journal of Geophysical Research, Vol. 90, No. C5, p. 9129-36.

Steffen, K., and Ohmura, A. 1985. Heat exchange and surface conditions in North Water, northern Baffin Bay. Annals of Glaciology, Vol. 6, p. 178-81.

Stirling, I., and Cleator, H. 1981. Polynyas in the Canadian Arctic. Ottawa, Canadian Wildlife Service. (Occasional paper No. 45.)

Swithinbank, C. 1960. Ice atlas of Arctic Canada. Ottawa, Canada. Defence Research Board.

Untersteiner, N. 1961. On the mass and heat budget of Arctic sea ice. Archives of Meteorology, Geophysics and Bioclimatology, Vol. 12, p. 151-82.

Vowinckel, E., and Orvig, S. 1966. Energy balance of the Arctic: V. Heat budget over the Arctic Ocean. Archives of Meteorology, Geophysics and Bioclimatology, Vol. 14, Nos. $3-4$, p. 303-25.

Walmsley, J.L. 1966. Ice cover and surface heat fluxes in Baffin Bay. Montreal, McGill University. Department of Meteorology. Arctic Meteorology Research Group. (Publication in Meteorology 84.)

World Meteorological Organization. 1970. Sea ice nomenclature. Geneva, WMO. 